\title{
VALUE CREATION, APPROPRIATION AND DISTRIBUTION: HOW FIRMS \\ CONTRIBUTE TO SOCIETAL ECONOMIC INEQUALITY
}

\author{
Hari Bapuji \\ Associate Professor (Strategy \& International Business) \\ Department of Management \& Marketing, The University of Melbourne \\ Melbourne, Australia \\ hari.bapuji@unimelb.edu.au \\ Bryan Husted \\ Professor, Department of Management, Entrepreneurship and Marketing \\ EGADE Business School, Tecnológico de Monterrey, Mexico \\ bhusted@itesm.mx \\ Jane Lu \\ Professor (Strategy \& International Business) \\ The University of Melbourne, Department of Management \& Marketing \\ Melbourne, Australia \\ Raza Mir \\ Professor of Management, Cotsakos College of Business \\ William Patterson University \\ MirR@wpunj.edu
}

August, 2017

Citation:

Bapuji, H., Husted, B., Lu, J., \& Mir, R. 2018. Value Creation, Appropriation and Distribution:

How Firms Contribute to Societal Economic Inequality. Business and Society, 57 (6): 983-1009. 


\title{
VALUE CREATION, APPROPRIATION AND DISTRIBUTION: HOW FIRMS CONTRIBUTE TO SOCIETAL ECONOMIC INEQUALITY
}

\begin{abstract}
Firms are central to wealth creation and distribution, but their role in economic inequality in a society remains poorly studied. In this essay, we define and distinguish value distribution from value creation and appropriation. We identify four value distribution mechanisms that firms engage in and argue that shareholder wealth maximization skews the value distribution towards shareholders and top executives, which in turn contributes to rising economic inequalities around the world. We call upon organizational scholars to study the value distribution role of firms and its consequences for society, and introduce the papers in this volume of the special issue on economic inequality, business, and society.
\end{abstract}

Keywords: Economic inequality, income inequality, value creation, value distribution, value appropriation, value capture 


\section{VALUE CREATION, APPROPRIATION AND DISTRIBUTION: HOW FIRMS CONTRIBUTE TO ECONOMIC INEQUALITY}

When we issued a call for papers for the special issue on inequality in late 2014, we had hoped to promote inquiry into the complex relationship between economic inequality, organizations, and society. It was spurred by the vast research in other disciplines, which had not only identified the numerous social ills arising from high economic inequality, but had also begun to advocate public policy interventions to reduce inequality (Neckerman \& Torche, 2007; Piketty, 2014; Wilkinson \& Pickett, 2009). We believed that management mattered as much to inequality as did public policy. So, our intention was to add the voice of organizational scholars to the emerging debate, and also to shed light on the complex relationship between organizations and society, from the prism of economic inequality.

As we head to print, however, the climate has changed significantly. Defying all predictions by scholars and analysts, the UK and US have moved in the direction of easing regulations and enacting protectionist measures in pursuit of economic growth and job creation. Similar winds are blowing elsewhere in Europe and other parts of the world. One question that has haunted the political and social scientists related to their inability to notice the simmering anger common people harbored against the establishment to such an extent that they had lost trust in the establishment and democracy's cherished ideals of freedom, equality, openness, and inclusiveness (Duggan, 2012). One issue that should warrant our attention as organizational scholars is: why had the massive economic growth fueled by corporations leave so many behind? The latest developments around the world lend to this issue an urgency that could not have been envisaged only a couple of years ago. This urgency to study economic inequality and its implications for organizations and societies should be felt more by organizational scholars 
because in late capitalist societies, firms are the primary sources of wealth creation and distribution (Bapuji, 2015).

In this introduction, we contend that inequality can be better understood at a theoretically robust level by paying equal attention to the interlinked, but distinct issues of value creation, value appropriation and value distribution by firms in a social context. Accordingly, we define and distinguish between these three issues and suggest that organization is the space in which value is created, but the inputs for value creation are provided by individuals (employees, managers, shareholders) and society (markets and institutions). We then argue that high levels of economic inequality being witnessed around the world are a result of value distribution being skewed towards some of these actors at the expense of others. Therefore, we call upon organizational scholars to focus on value distribution role of firms to devise strategies to mitigate the harmful consequences of rising economic inequality to firms and societies.

\section{Economic Inequality and Value}

Although research on economic inequality is vibrant, much of it has been focused on examining the effect of economic inequality on various societal outcomes, such as health, crimereduction, and wellbeing (Bapuji, 2015). Given this focus, economic inequality has traditionally been conceptualized and measured as inequality in wealth and income. However, to better understand economic inequality and its consequences to business and society, it is necessary to focus on unevenness in the dispersion of resource endowments, uneven access to productive resources, and uneven rewards for labor (Bapuji, 2015). Organizations alone do not influence the dispersion in resource endowments and access to productive resources; the institutional environment plays a much larger role in resource endowment and access. By contrast, organizations play a central role in assigning rewards for labor and other productive resources 
used in value creation (Bapuji \& Neville, 2015). Therefore, in this article, we focus on value creation and distribution of rewards by firms to delve into the relationship between economic inequality, business, and society.

Value creation and capture explain the questions of both firm boundaries and sustainable competitive advantage (Mahoney \& Qian, 2013). Accordingly, considerable research attention has been paid to value creation and capture. This research suggests that organizations create economic value through products and services that customers find valuable and are willing to pay a price for (Bowman \& Ambrosini, 2000; Lepak et al., 2007). Accordingly, this literature has largely focused on the strategies that firms use to create value, such as innovation or acquisition of unique resources. In contrast to value creation, the literature on value capture is concerned with the extent to which shareholders capture the value, and how capture by shareholders is at risk due to appropriation of value by "other stakeholders, such as employees, competitors, or society" (Lepak et al., 2007:187; Coff, 1999).

Although a notable stream of research has examined value creation and capture, the literature lacks consistency in the use of terms or consensus around definitions (Lepak, Smith \& Taylor, 2007). Researchers have used a number of terms - in an interchangeable fashion - to denote value and explain it. These terms include value, rents, appropriation, capture, distribution, realization, and allocation (Bowman \& Ambrosini, 2000; Makadok \& Coff, 2002; Lepak, Smith \& Taylor, 2007; Priem, 2007). The varied usage of these terms arises due to a combination of disciplinary orientations of researchers, the different analytical levels at which value creation and capture occur, and the difficulty in differentiating the content of value from the processes through which it is created (Lepak, Smith \& Taylor, 2007). Further, confusion arises due to what 
value means to various stakeholders, such as organizations, customers, suppliers, and shareholders (Bowman \& Ambrosini, 2010).

As a first step in unpacking the concept of value to distinguish its content from the processes of its creation and use, we delineate three distinct processes: value creation, value appropriation, and value distribution. In defining value creation, appropriation, and distribution, we broadly follow Bowman \& Ambrosini (2000) and Lepak, Smith \& Taylor (2007). One important distinction we make is that we view value capture as consisting of two distinct processes: appropriation of the created value by firm, and distribution of surplus among claimants (Moran \& Ghoshal, 1999). This distinction is important to understand the role of firms in economic inequality.

\section{Value Creation, Appropriation and Distribution: Definition and Distinction}

In bringing together value creation and capture research into focus, Lepak et al, (2007) suggest that value creation occurs at multiple analytical levels: individual, organization, and society. When the individual is the unit of analysis, the focal process is the creative acts displayed by individuals and a select set of individual attributes, such as ability, motivation, and intelligence, and their interactions with the environment. When the organization is the source of value creation, issues regarding innovation, knowledge creation, invention, and management gain prominence. Finally, at the societal level, the level of entrepreneurship and macroeconomic conditions in the external environment, including laws and regulations restricting or encouraging innovation and entrepreneurship, come into play (Lepak et al., 2007:183). In this essay, we take an organizational perspective and draw insights from the literatures on organizational learning and innovation to explain value creation, appropriation, and distribution. 
From a firm's perspective, value creation is the "production of goods or services that a consumer is willing to buy." This is similar to what Bowman \& Ambrosini (2000) refer to as use value. Accordingly, value depends on the subjective perceptions of a potential consumer about the value of goods or services on offer and remains latent at this stage (Moran \& Ghoshal, 1999). This definition does not include the production cost of the goods or services. This is because the value of a good to a user does not necessarily depend on the price at which it is offered; the price influences a user's purchase decision, but not a product's value to the user. This is akin to the Marxian distinction between "use value" and "exchange value" of commodities. In other words, the value of a good differs according to the consumer and production cost becomes an issue only when price is considered. Given the subjective nature of use value to consumers, value creation by a firm is best reflected in consumer demand for its products and services. Therefore, the overarching question guiding value creation is "how to maximize the appeal of a product/service to the consumer?"

Value creation occurs primarily through combination and exchange of resources (Moran \& Ghoshal, 1999; Nahapiet \& Ghoshal, 1998). Combination involves deploying a variety of resources in a new fashion to create new products or services, while exchange involves combining resources in a more productive way to improve existing products or services (Moran \& Ghoshal, 1999). The resources combined and exchanged include both tangible factors of production, i.e., land, labor, and capital (Barney, 1986; Dean \& Kretschmer, 2007); and intangible resources, such as knowledge, intellectual capital, and reputation (Fombrun \& Shanley 1990; Hall, 1993; Nahapiet \& Ghoshal, 1998). Increasingly, value creation in the knowledge economy involves intangible resources, such as learning and knowledge (Kang, Morris \& Snell, 2007). 
Value appropriation is the "production of goods and services at the lowest possible cost and their sale at the price closest to consumers' willingness to pay." This is similar to what Bowman \& Ambrosini (2000) refer to as exchange value, but also incorporates production cost because it is framed from the perspective of a firm. Further, our conceptualization of value appropriation is an umbrella construct to capture the numerous activities firms engage in to minimize costs and maximize revenues. Value appropriation depends on the price a consumer has paid for the product or service of the firm, and amount it cost the firm to product the product or service. Therefore, unlike value creation that occurs primarily within the boundaries of an organization, value appropriation occurs both within the organization, and outside - in the market place. The overarching question guiding value appropriation is "how to maximize retained earnings for the firm?"

Firms appropriate the value they create by employing a number of corporate level and business level strategies, aimed at cost minimization and revenue maximization (Bapuji, 2015). Strategies deployed by firms to appropriate value include cost reduction strategies through sourcing of raw material from low cost suppliers, and process improvements to reduce or eliminate redundant expenses. Value appropriation strategies also include revenue enhancement strategies, such as creating larger/global markets, and differentiation to extract the highest exchange value from customers. Further, firms also engage in non-market strategies to lobby governments to reduce taxation and regulations to minimize costs of production. Additionally, firms also engage tax minimization strategies through distribution of production, innovation, and coordination functions to maximize retained earnings.

Value distribution is the "allocation of retained earnings among those who contributed resources to value creation and appropriation.” Although previous research has not explicitly 
labeled it as value distribution, it has examined the distribution of retained earnings among shareholders; on rare occasions, when other stakeholders (e.g., employees) are considered, the analysis was limited to the factors that enable employees to appropriate the value for themselves instead of passing it on to shareholders (Coff, 2010).

Value creation and appropriation often occur under uncertain conditions. The stakeholders who provide the resources cannot, ex ante, know what level of value will be created (Kim \& Mahoney, 2010; Lepak et al., 2007; Mahoney \& Qian, 2013). Similarly, managers and executives who develop and implement strategies of value appropriation cannot, ex ante, know how much value they can appropriate. Therefore, firms use a range of incomplete contracts to access the resources they need to create value and appropriate it (Coff, 1999; Kim \& Mahoney, 2010). Some of these contracts are more explicit and transactional in nature, e.g., contracts with suppliers of raw materials and buyers. But, others are less explicit and psychological in nature, e.g., contracts with shareholders, organizational members, government, and society at large. Therefore, value distribution tends to be a complex socio-political process that various claimants (i.e., those who provided direct and/or indirect resources for value creation and appropriation) engage in.

Our primary thesis is that when value distribution is skewed towards a few of these claimants, it will contribute to economic inequality. We delve into this in the next section by identifying stakeholders who contribute directly and indirectly to value creation and appropriation, and how retained earnings have been distributed among them in the recent decades.

\section{Value Distribution and Inequality}


Our analytical focus to understand value creation, appropriation, and distribution is predominantly at the organizational level. Accordingly, following Lepak et al., (2007), we develop our arguments by drawing on insights from innovation and organizational learning literatures. The literature on learning and innovation has revealed three important insights that are necessary to understand the role of various actors in value creation and appropriation, and thus the claimants to value distribution. First, knowledge creation and learning involve individuals and their interactions with others (Felin \& Hesterly, 2007; Grant, 1996; Nonaka, 1994). For example, Crossan, Lane and White (1991) suggest that organizational learning begins with intuition, which is an unconscious process of seeing patterns and differences, and connecting them to form plausible new combinations. When individuals come together in an organizational space, they bring to the fore their intuitions, which are interpreted by others through comparison and contrast with existing knowledge. The interpreted knowledge is integrated with existing knowledge, leading to the creation of new knowledge. Such integrated knowledge is then institutionalized at the organizational level in the form of systems, structures, strategy and procedures. In short, although individuals are the agents through which new knowledge is created, knowledge creation itself is a social process that is aided by organizational context.

Second, the above mentioned interactions between individuals not only occur within an organization, but also outside the organization. For example, individuals acquire knowledge from industry/professional associations (Hanssen-Bauer \& Snow, 1996), patents, conference presentations, publications (Liebeskind, Oliver, Zucker, \& Brewer, 1996), and informal networks between employees of different firms (Appleyard, 1996). Further, firms often acquire knowledge from outside the organization through cooperative ventures (Shenkar \& Li, 1999), strategic 
alliances (Hitt, Dacin, Levitas, Arregle \& Borza, 2000), and networks (Hanssen-Bauer \& Snow, 1996; Lee, Lee \& Pennings, 2001). Additionally, firms also create new knowledge with the help of technologies acquired from suppliers, customers, competitors, industry associations, and research communities (Powell et al., 1996; Takeishi, 2001). These external social interactions often repeat over time as the knowledge evolves (Nonaka, 1994; Tsoukas, 1996). In other words, although knowledge is created in an organizational space, it is often aided by interactions with those outside the organization.

Third, innovations created by organizations occur within the ambit of a national innovation system (Freeman, 1987; Nelson, 1993; Patel \& Pavitt, 1994; Lundvall, 2007). A national innovation system (NIS) refers to the network of public and private institutions that fund and perform R\&D, develop innovations from it, and facilitate diffusion of new technologies. Specifically, an NIS includes (a) public agencies that support or perform R\&D, (b) universities that perform basic research as well as train knowledge workers, (c) private firms that invest in R\&D or in commercialization of new technologies, and (d) a regulatory framework that enforces intellectual property rights (Mowery \& Oxley, 1995). Some scholars have also expanded the concept of NIS to include cultural aspects such as cooperation, labour relations, learning culture, and commitment to social well-being, among others (Cooke, Uranga, \& Etxebarria, 1997). In short, knowledge creation is facilitated by national innovation systems in a country.

Taken together, the above insights suggest that even though value creation and appropriation appear to occur within firm boundaries, the processes and resources involved in value creation and appropriation are not solely dependent on any one actor; a range of productive resources provided by members of organization and society is used to create and appropriate value. These include organizational members (i.e., employees, managers, and executives), 
shareholders, government, and the broader society. While some of these (e.g., employees, managers, executives, and shareholders) directly contribute resources, others (e.g., government and broader society) contribute resources indirectly.

Given the nature of resources contributed, the uncertainties in the processes of value creation and appropriation, and the incompleteness of contracts, the distribution of appropriated value depends on the bargaining power of those who contributed productive resources. Their bargaining power, in turn, is determined by their access to key information, their ability to take action, their replacement costs to the firm, their perceived dependence on firm, and the costs of switching faced by these claimants (Bowman \& Ambrosini, 2010; Coff, 1999). In addition, the legitimacy of their claim too is an important factor influencing the distribution.

We present the relative bargaining powers of each claimant in Table 1 and explain below how those relative bargaining powers influenced uneven value distribution via four mechanisms: compensation, dividends, taxes, and philanthropy. It is important to note that these bargaining powers pertain only to claims for value distribution, and not bargaining power of these actors in general. Although country-level differences exist in the relative bargaining powers of various claimants, our representation in the table below is intended to illustrate the relatively high power of shareholders and top executives, particularly evidenced in the developed economies.

Please insert Table 1 about here

\section{Compensation and Inequality}

Organizational insiders - employees, managers, and executives - are the most immediate claimants to the value created and appropriated in organizations. However, their bargaining 
power depends on their position within the organization. Employees at the lower end have limited bargaining power, while executives have a higher bargaining power, with managers falling somewhere in between depending on their skillset. This is reflected in the vast difference in their compensations. It is important to note that differences in compensation are not necessarily negative; compensation differences allow organizations to design incentives and rewards to achieve and augment performance. In fact, highly equal pay distributions are inequitable because they do not suitably reward employees for the utility of their inputs for value creation and appropriation (Trevor, Reilly \& Gerhart, 2012). However, in the process of creating incentives and controlling costs, organizations can segregate work into high- and low-skilled jobs, often through strategies such as outsourcing and/or offshoring that aim to contract out and/or relocate jobs to countries with lower factor costs. Consequently, workers at the lower end lose their voice and cannot exercise the option to exit (Mir, Mir \& Bapuji, 2006). With the rise in outsourcing/offshoring, even large companies now employ fewer people directly, but those employed can be finely segregated and thus the wage dispersion can be justified as equitable (Cobb \& Stevens, 2016). The segregation of jobs has created reward structures that provide generous salaries and lavish bonuses at the executive level, but tenuous, temporary jobs and near-poverty wages at the bottom level, with very little in between.

The role of compensation structures in inequality is fundamental because wages and salaries account for $75 \%$ of incomes among working-age adults (OECD, 2011). As business firms are driven by the principle of shareholder wealth maximization (Sundaram \& Inkpen, 2004), stock options and performance-based compensation to resolve principal-agent problems have become the norm (Boyd, 1994; Finkelstein, Hambrick, \& Cannella, 1996). This has led to the rise of an executive class, whose income derives from managing organizations. Research 
shows that the rise in the upper end of the wage spectrum has had a decisive impact on overall income inequality (CBO, 2011; OECD, 2011; Kim, Kogut \& Yang, 2013; Lemieux, 2006). Examining the patterns in inequality, Piketty \& Saez (2003) found that the working rich have replaced the rentiers at the top of the income distribution.

Although employees tend to have lower bargaining power, they can enhance it through unionization, which has shown to increase both union and non-union wages (Western \& Rosenfeld, 2011). However, with the decline of unions in the US and much of the industrialized world, the power of the vast majority of employees has decreased considerably (Coff, 1999). As a result, their salaries have considerably dropped in real terms in some cases, and stagnated in others. This is evidenced by declining wage premium for those in the lower and middle levels of an organization, contributing to overall inequality (Cobb \& Lin, 2017).

\section{Dividends and Inequality}

Organizational research and practice typically assume that shareholder wealth maximization is the sole concern of business organizations (Nag, Hambrick \& Chen, 2007). As a result, shareholders have the most well-defined claim to any value created and appropriated by an organization. In addition, their bargaining power is also high owing to their access to information and ability to take action against the executives. Further, being the owners of the firm, shareholders cannot be easily replaced; at least, not without significant costs. Given the portable nature of financial capital, the shareholders do not depend on the company and can easily shift their resources to another company. Shareholder gains get further sedimented in the hands of the wealthy as capital gains. As a result, shareholders - particularly the institutional investors hold high bargaining power and receive a lion's share of the value created and appropriated by organizations (Lazonick \& O'Sullivan, 2000). Since the 1980s, in the US and 
developed economies, the institutional investors and savings and loan institutions became prominent sources of capital and shifted the focus of corporations away from "retain and reinvest" to "downsize and distribute". Under a shareholder-value regime, downsizing and layoffs became a common feature and continued even after performance of firms and economy improved (see Lazonick \& O’Sullivan, 2000 for a detailed exposition on this matter).

While downsizing and layoffs themselves directly contribute to income inequality by suppressing wages, a more direct effect could be found in how the value was distributed to shareholders through dividends and stock repurchases. Compared with the 1960s and 1970s, corporate pay-out ratios (i.e., corporate dividends as a percentage of corporate profits) increased significantly in 1980s and 1990s (approximately 42 percent and 49 percent, respectively) and continued even when profits declined. Further, stock repurchases became more common and increased from roughly $5 \%$ in the late 1970 s and early 1980 s to between 20 and 25 percent of corporate profits during the late 1980s and mid 1990s (Lazonick \& O’Sullivan, 2000). This situation in the US is repeated elsewhere in the world too. For example, corporate dividends in the UK as a percentage of corporate profits were 10 percent in 1970, but reached over 60 percent in 2015 (Weldon, 2015). In India, they increased from 27.26 percent in 2004 to 34.52 percent in 2014 (Shah \& Ramarathinam, 2015)

In additions to dividends and share repurchases, corporations may use cash holding as a strategy to enable future distributions to shareholders and executives. In effect, cash holding blocks the value distribution to employees and other claimants. Not only that, cash holding prevents firms from engaging in further value creation and appropriation. For example, Apple reportedly holds $\$ 250$ billion in cash, while U.S. companies in total are reported to hold over two 
trillion dollars of untaxed profits (Heath, 2017). Interestingly, the majority of this cash held by companies is in overseas accounts, primarily to avoid taxation in the U.S. (Chasan, 2013).

The discussion above shows that corporate governance driven by shareholder wealth maximization tends to intensify income inequality by distributing a substantial portion of the retained earnings to shareholders (Sjoberg, 2009). This is also borne out by evidence in organizational research. For example, David and colleagues found that value from diversification was appropriated as profits to shareholders when shareholders took a transactional approach, but was appropriated by employees (salaries and employment growth) when shareholders took a relational approach (David, O’Brien, Yoshikawa \& Delios, 2010).

\section{Taxation and Inequality}

Typically, productive opportunities are identified, created and exploited at the intersection of firm and the society (Moran \& Ghoshal, 1999). Through legislation, protection of various property rights, and maintenance of law and order, the state creates the conditions necessary for firms to create and appropriate value. Therefore, paying income taxes is one of the means by which organizations can distribute value to society and government (Lepak, Smith \& Taylor, 2007). Taxation revenues allow the state to promote the development of human capital through education and health, and protect citizens against adverse shifts in their material wellbeing with a social safety net. Such actions protect against long-term disadvantages stemming from poverty and income shortfalls, and allow for upward mobility (DiPrete \& McManus, 2000; Kenworthy, 1999). In other words, tax revenue allows the state to develop human capital and create the conditions necessary for firms to create and appropriate value.

Although governments seek a share of the retained earnings through various forms of taxation, firms often resist these attempts and achieve a favorable tax regime. For example, 
research has found that firms who devote resources to tax lobbying accrue considerable benefits in terms of their effective tax rates (Richter, Samphantharek \& Timmons, 2009). When tax systems are biased by exemptions targeted at the rich, the tax base and progressivity may shrink, increasing income inequality (Gupta, Davoodi \& Alonso-Terme, 2002).

In addition to lobbying, the mobility of capital across borders makes it difficult for governments to demand and receive a higher share from the earnings retained by organizations. As firms seek tax arbitrage by setting operations in tax-friendly locations (Ghemawat, 2003; Hong \& Smart, 2010; Kogut, 1983), demand for offshore tax services continues to rise (BCG, 2012). Firms are able to avoid paying taxes through a range of techniques, including treaty shopping, transfer pricing, and use of shell companies in tax havens, such as the Netherlands, Bermuda, Luxembourg, Ireland, Singapore, and Switzerland (Zucman, 2014). The use of tax havens and the share of profits reported through shell companies in tax havens has continued to rise since 1980s; An estimated amount equivalent to 10 percent of GDP is held in global tax havens (Zucman, 2013). As a result, the loss of taxes to governments is estimated to be at least $\$ 190$ billion (Zucman, 2014).

Even the governments of developed nations appear powerless in the face of tax evasion by large corporations. For example, the US granted a repatriation tax holiday in 2004, allowing companies to bring back profits to the country if they paid a rate of 5.25 percent. While a number of firms used this opportunity, they also shifted those profits back to tax havens in the years after, resulting in the share of US corporate profits held in tax havens to go back to previous levels and rise since 2006 (Zucman, 2014). The executives of many companies are demanding a similar tax holiday now. For example, Tim Cook, the CEO of Apple said that his company would not bring back the money to the US until there was a "fair rate" (Heath, 2017). 
As tax avoidance rises, inequality increases, which in turn makes tax evasion acceptable (You \& Khagram, 2005), and tax avoidance rampant (Christie \& Holzner, 2006). In other words, tax avoidance and inequality form a vicious cycle. Not surprisingly, in countries where tax systems once had a redistributive role and contributed to human development, reforms and austerity have led to higher inequality now (OECD, 2011).

\section{Corporate Philanthropy and Inequality}

Society is a claimant in the value distribution process for two main reasons. First, society allows the supply of productive resources for value creation and appropriation. Although the suppliers are the visible face of resources that a firm sources, the ultimate facilitator of resource allocation is the society, which grants a social license to firms and their business (Gunningham, Kagan, \& Thornton, 2004). Second, society bears the residual risks and absorbs the environmental and social costs of business. However, society is a fragmented entity and is often a label for unidentified stakeholders in an analysis (Clarkson, 1995; Freeman, 1984). As a result, the claims of society are reflected in multiple demands on firms to engage in corporate social responsibility (CSR) or corporate philanthropy. Prospective employees can demand or reward a positive social impact (Turban \& Greening, 1997). NGOs, nonprofits, and social movements can mobilize consumer pressure to force investment into social responsibility (Aguilera, Rupp, Williams \& Ganapathi, 2007; McDonnell \& King, 2013). Media scrutiny can force companies to invest in CSR (Reverte, 2009); industry and firm social norms and shared values may create pressure for firms to behave responsibly out of a need for legitimation (Aguilera et al., 2007).

Although CSR and corporate philanthropy can theoretically decrease inequality by distributing value to society, and away from other powerful claimants, research evidence suggests that the shareholder profit maximization motive reduces expenditures on philanthropy 
(Bartkus, Morris \& Seifert, 2002). Even when corporations do engage in philanthropy, they often do so in order to preemptively buffer themselves from criticism of their bad acts (Godfrey, 2005) or to protect their reputation in times of crisis (Muller \& Kraussi, 2011). In other words, donations may be used principally as a marketing tool (Burt, 1983; Moir \& Taffler, 2004).

Even when organizations engage in philanthropic activities, they may focus their contributions on organizations or causes that serve to reify existing power structures (Domhoff, 2009). Giving may have an elite bias, particularly in the developed world (Marquis, Glynn \& Davis, 2007); a housing project for the poor, for instance, might not draw the same corporate attention as an elite business school's building campaign. Similarly, companies can also direct their CSR outlays to vanity projects, including building of statues as done by some Indian public sector companies (Ranjan, 2017). Such corporate philanthropy efforts might have little effect on -- or perhaps even intensify - the levels of income inequality in a country.

In sum, a wide range of factors determine and influence income inequality, some well outside the boundary of the firm ${ }^{1}$. However, as primary sources of wealth creation in the society, the manner in which organizations distribute the value they create and appropriate plays a significant role in the income inequality levels in a country. The principle of shareholder wealth maximization and the resultant corporate governance structures have enabled the distribution of a lion's share of value to executives and shareholders, while employees, government and society are left with limited share of the value. Such skewed distribution of value not only creates inequality, but also may hamper future value creation and appropriation (Bapuji, 2015; Bapuji \&

\footnotetext{
${ }^{1}$ See McCall \& Percheski, 2010, for a review; see OECD, 2011 for a review and empirical assessment of the relative weights of various factors that determine income inequality, including globalization, technology, education, and tax policy
} 
Neville, 2015). We discuss some of these issues and their implications to organizational research, before we introduce the papers in this special issue.

\section{Placing Society Prominently in Value Creation, Appropriation and Distribution}

In this article, we contend that the underlying issues of economic inequality remain salient to business and society, and we as organizational researchers ignore them at our own peril. Modern firms have achieved an enormous success in creating economic wealth, and organizational researchers have aided in it by studying value creation and appropriation. However, organizations - and by extension organizational researchers - have fallen short in value distribution to various stakeholders, and thus have contributed to the current high levels of economic inequality.

Implicating organizational scholars for the corrosive levels of economic inequality might sound harsh, but we have undoubtedly become complicit in the production of inequality because of the choices we make about the issues that we study and ignore; for example, highlighting the beneficial effects of globalization without paying similar attention to local labor markets, examining falling unionization without studying its negative impact on wages and work conditions, and analyzing growth without paying attention to its distributional skews. In the continuum of individual-organization-society, organizational scholars have paid more attention to the first link than the second; focusing more on the role of individuals and firms in value creation and appropriation, while overlooking the role of society in the same. Similarly, organizational scholars have studied the distributional benefits of firm profits to shareholders and executives, but have rarely studied the claims of society and the state, and the benefits that can accrue to corporations by sharing profits with them. 
Inequality impacts organizations at all three levels of the value paradigm. At the level of value creation, the contributions of individuals at the lower end of the power equation end up being ignored in a systematic way. We are conditioned by the orthodoxies of our field to argue that value is created by the upper echelons of the firm, with lower rungs of organizations providing nothing but a support role. Often, the micro processes by which knowledge seeps into firms are ignored and elided by researchers. A firm that operates in multiple geographic and institutional environments, uses a variety of vendors and contractors, incorporates a plethora of foreign and indigenous modes of operations into its own routines but ends up being credited with its value creation as if it was a solo actor operating in a vacuum. Apple is a case in point (Lehman \& Haslam, 2013). At the intra-firm level, credit for value creation and appropriation is arrogated to the top management, which of course sets the stage for unequal compensation practices, the representation of lower level workers as dispensable and contingent sources of undercompensated labor, and the sedimentation of the idea that firms that create and appropriate value do not need to give back to the context that made this value creation possible. As organizational scholars, we need to reflect on the importance we place on the role of top managers in firm performance, and whether the same is justified.

Likewise, value distribution to the providers of capital is actively encouraged through a regime of property rights and regulations. Regimes of taxation get represented as unjust demands on a firm, customers are made to pay inflated prices through opaque forms of value representation that in turn obscure the often exploitative conditions under which production occurs and the acquisition of public resources through regimes of accumulation by dispossession (Harvey 2003) is ignored while calculating the cost of production. The fetishization of exchange value is accomplished by delinking products from the conditions under which they were 
produced. A beautiful handbag or smartphone is best sold when it can be linked to a pleasant user experience, which means that it must not be associated with the conditions under which it was produced, the wages earned by the workers who produced it, or the environmental impact of the factories where it was produced (Hudson \& Hudson, 2003). Firms route their sales through tax havens to take advantage of arbitrage opportunities offered by their spatial spread, maximize their accumulative powers at the expense of social claimants such as governments, and locate polluting production facilities in countries with lax environmental protocols, thereby maximizing their value appropriation, and reducing the ability of governance mechanisms to police and allocate appropriate costs to their actions.

To make the value creation and appropriation actions of corporations accountable to the societies in which they operate, organizational researchers need to study these phenomenon comprehensively, and from the perspectives of all stakeholders. But, it remains a powerful indictment of our field that organizational researchers have been relatively silent on the effect of firms on the societies in which they operate, and the role of firms in value creation and distribution by firms. For example, management research has studied firm actions relating to compensation, training, vertical integration, outsourcing, and offshoring - all of which have an effect on economic inequality, but have rarely viewed these actions through the lens of their distributional consequences for societal wellbeing. Research in human resource management and organizational behavior has been concerned about wage dispersion and its consequences within the firm, but rarely examines its broader social consequences beyond the firm (Greenberg, 2010). Similarly, the literature and research on corporate social responsibility has, at best, offered only marginal treatments of income distribution. Issues related to living wages, fair trade, and poverty have occasionally been explored, but questions about the broader corporate role in fostering 
inequality remain unanswered (Utting, 2007). In fact, research on phenomena such as "the base of the pyramid" has often deployed poverty as an opportunity, suggesting micro-strategies for firms to extract further value from the poor, with scarce consideration for the welfare of those who they seek to transform into consumers.

In addition to focusing on the role of society and government in value creation and appropriation, organizational researchers need to study value distribution and its consequences. Currently, value distribution is skewed heavily toward capital market stakeholders of the firm, principally shareholders (and peripherally, holders of debt). The logic of the shareholder being the residual claimant of the organization is adopted to squeeze value out of the "supply chain," a denatured term that functions to obfuscate the reality that this chain comprises humans whose livelihood is compromised and whose misery is exacerbated by reduced compensation (Kaplinsky \& Morris, 2001). So, suppliers are short-changed, employees are downsized, governments starved of tax revenues, all in favor of the shareholder, who benefits doubly, first from increased dividend payouts and then from capital gains that accrue when firms are rewarded for such behavior by increased market capitalization (Haslam et al., 2013).

It is important that organizational scholars put a human face to the victims of such inequities, and to make some bold statements: inequality leads to misery among its victims. It makes people physically and mentally sick, it increases crime, reduces life expectancy, and substantially reduces the quality of life among those at the receiving end of unequal relations (Wilkinson \& Pickett, 2009). The problems of inequality are not confined to absolute socioeconomic status, but relative status as well. For example, the fact that the poor of developed nations are better off than the poor in far-flung parts of the world does not reduce their misery. Likewise, an unequal society affects not just the poor but all sections of society (Weich, Lewis 
and Jenkins, 2001). And as researchers of firms, we need to be cognizant of the increased role played by firms in fostering this inequality and in undermining institutions of social welfare.

We have alluded in this article to the potential of skewed distribution to endanger future value creation and appropriation, via decreased human development and poor institutional infrastructure. But, recent events in the macrosocial realm show that those consequences need not manifest in such a linear fashion. For example, election of protectionist/nationalist governments is one way in which unequal distribution can have disruptive consequences for organizations. Similarly, protest movements and the resultant support for alternative organizational forms can seriously undermine the ability of firms to create and appropriate value (Bapuji \& Neville, 2015). The neoliberal turn in the world economy over the past few years risks undermining a social compact several decades in the making.

In sum, to better understand the role of organizations in societal inequality, as well as to examine the detrimental consequences of inequality to organizations, organizational researchers need to carefully focus on the relationship between business and society. To achieve this, we suggest that organizational scholars study (i) the role of society and governments in value creation and appropriation, (ii) the claims of government and society to value distribution, and (iii) the consequences of skewed value distribution to firms and societies, in the form reduced opportunities for future value creation and appropriation, as well as in the form of lower human development. The papers in this special issue, presented below, serve as powerful illustrators to the need to examine these issues.

\section{Paper in this volume of the special issue}

Echoing our sentiments that management mattered to societal economic inequality, a number of our peers responded positively to our call, with innovative approaches to study 
inequality and offering high quality research for publication. In this volume, we present a set of eight papers that deal with the societal context of inequality as well as the challenges researchers face in studying inequality.

The first paper in this volume by Ivana Katic and Paul Ingram examines the mechanisms that drive the relationship between income inequality and subjective wellbeing. They find that income inequality increases the subjective wellbeing of the individuals with higher incomes, but reduces the wellbeing of those who believe that income generation processes are unfair and of those who believe that they have a chance of upward mobility. Presenting both the results that supported their theoretical arguments as well as those that ran counter to their arguments, the authors infuse a refreshing objectivity to the debate on inequality and wellbeing. More importantly, they have developed a website (www.inequalityandswb.com) where they made their data available for other scholars to study the relationship; yet another healthy research practice.

Katic \& Ingram (2017) present a well-researched and thoroughly conducted empirical study that attempts to bring clarity to the relationship between inequality and subjective wellbeing. This illustrates the benefits that organizational researchers can bring if they studied economic inequality. Their study showing the contingent effect of income inequality implies that inequality enhances the wellbeing of the rich, while decreases that of the rest. This has implications for their ability to participate in value creation and appropriation, and more broadly to function as productive individuals in the society.

Michael Elmes presents a paper focused on food security in the US. It suggests that economic inequality and the consequent growing levels of poverty, have resulted in obesity, a direct consequence of the poor eating unhealthy food for survival. This focus on survival leads to an erosion of "equality of capabilities" and undermines their ability to play a "full and active part 
in the functioning of (their) community." Unequal access to nutritious foods in the United States, Elmes (2017) argues, is attributable in part to an industrial food system that is designed to produce short-term profits for producers, processors, and distributors at the expense of the longterm benefits for consumers, food workers (including farmers), and ecosystems. By highlighting how organizational strategies aimed at value appropriation and skewed distribution of surplus can have a negative effect on the capabilities of individuals, particularly those at the bottom of the society, Elmes (2017) illustrates the need to study the effect of firm strategies on societies and individuals. Further, his paper also warns of the dangers of such strategies to firms themselves by pointing to the protests and regulations by those disadvantaged.

Maureen Scully, Sandra Rothenberg, Erynn Beaton and Zhi Tang examine ways in which wealthy individuals can be mobilized to make common cause with their underprivileged allies to expose and contest the root causes of wealth consolidation. Scully and colleagues distinguish this activism from the regimes of "philanthrocapitalism," whereby the wealthy give only after they have accumulated huge gains, and often for self-interested motives. Their paper constitutes a clear-eyed acknowledgment that inequality is reproduced through organizations, and also highlights the potential of philanthropy to reduce inequality through "privilege work," a process that enables wealthy but socially conscious actors to deploy their wealth as a tool for change. The paper engages with the relationship between philanthropy and inequality discussed earlier in this essay, and emphasizes the need to understand the processes of privilege work to help those willing to use their own status for the benefit of the disadvantaged.

Krista Lewellyn's paper explores the manner in which income inequality may be caused by entrepreneurial activities and institutional contexts. She uses data collected from multiple sources to construct a sample of 38 countries and deploys a configurational approach to analyze 
how various combinations of entrepreneurial activities and institutional contexts produce inequality. She concludes that high-growth and/or economic activity are not sufficient to prevent income inequality; rather in some cases, they exacerbate the widening income gap between different societal actors. Specifically, Lewellyn (2017) shows that high income inequality is likely to result from high-growth entrepreneurship when such entrepreneurship occurs in institutional contexts with capital-based financial systems, and that promote reductions in wages. These findings illustrate how high-growth entrepreneurship characterized by the presence of large corporations increased income inequality when it follows the principle of shareholder wealth maximization - reflected in capital-based financial systems and a reduction in wages to employees. By showing the effect of various institutional contexts on entrepreneurship and inequality, Lewellyn also highlights the need to study the effect of national institutional infrastructure on value creation, and thus the need to consider the claims of governments - and societies at large - to value distribution.

Saurav Pathak and Etayankara Muralidharan analyze the relationship between income inequality and the emergence of social entrepreneurship. Using data from the Global Entrepreneurship Monitor survey, they demonstrate that country-level income inequality increases the likelihood of individual-level engagement in social entrepreneurship, while income mobility constrains it. They also suggest that income mobility negatively moderates this relationship, concluding that a combination of low income mobility and high income inequality is a predictor of social entrepreneurship. The paper takes the discussion of inequality into the important area of social entrepreneurship as an area to study. In doing so, it also raises the need to study whether social entrepreneurship can mobilize those marginalized by inequality, or does 
social entrepreneurship get deployed more as a way to normalize and legitimize regimes of inequality, at least in certain institutional contexts (Lewellyn, 2007).

The paper by Michael Carney and Robert Nason utilizes data from the triennial survey of consumer finance, and shows that there is substantial heterogeneity within the upper crust of the unequal society as well. This group own relatively modest fortunes and are neither rentier capitalists nor overpaid executives, but derives a significant share of its wealth from ownership and active management of small- to medium-sized private enterprise. The paper suggests that divided ideological positions obscure the presence of family firms in the wealthiest $1 \%$ households, and thus, their role in income inequality. Carney \& Nason (2017) argue that by fusing ownership and management, family firms create jobs and economic growth, while also perpetuating privilege, ownership, and wealth across generation. By bringing the family businesses into the picture, this paper raises important questions about the governance in family firms, as well as their role in income inequality.

Amir Shoham and Sang Mook Lee investigate the impact of language on gender wage inequality and country income inequality. Analyzing data from 163 countries over nine year, they conclude that nations with a higher level of gender marking in their dominant language have a higher wage gap between genders, which in turn has an effect on country income inequality. Their paper helps us understand how language has an indirect impact on country income inequality via gender wage inequality within a society. The paper has the potential to help policy makers better understand the environment that influences inequality in general and inequality between genders in particular. Shoham and Lee (2017) also serves as a powerful illustrator of the unknown ways in which institutional contexts affect income inequalities in a society - whether 
specifically across various demographic groups, such as race or gender (Bapuji \& Mishra, 2015) or more generally beyond demographic considerations.

The final paper by Richard Marens suggests that rampant inequality demands that scholars need to study the corporate practices that contribute to this trend. He points toward empirical work that has begun such an analysis, examines alternate methods of theory construction that go beyond the experimental science model of theory building, and provides an example of a social science theory based on the work of Hyman Minsky that exemplifies how empirically informed open theory can illuminate the dynamics behind growing inequality. Offering a critical view of the business and society scholarship, Marens (2017) points to the need for organizational scholars to revisit their theoretical assumptions and empirical approaches to study economic inequality.

In conclusion, this special issue has presented some arguments that can offer a basis for a nuanced examination of the processes of value creation, appropriation and distribution, as well as offer a frame to examine the interdependence between business and society. Together, these can broaden the scope of management theory and deepen our understanding of organizational performance as well as societal wellbeing. We believe that by examining the complex interrelationship between business and society with the prism of economic, organizational scholars can develop richer management theory, as well as inform other disciplines that examine societal level phenomenon, particularly those that study economic inequality. We hope this special issue will be an important first step in that direction. 


\section{Table 1: Bargaining Power of Claimants Providing Productive Resources}

\begin{tabular}{|l|l|l|c|c|c|}
\hline Factor \& Claimant & Employees & Executives & Shareholders & $\begin{array}{l}\text { Governmen } \\
\text { t }\end{array}$ & Society \\
\hline Legitimacy of claim & Low/Medium & Medium & High & Low & Low \\
\hline Access to information & High & High & Medium & Medium & Low \\
\hline Ability to take action & Medium & High & Medium & Medium & Low \\
\hline Replacement costs to firm & Medium & High & Medium & Low & Low \\
\hline Perceived dependence on firm & Medium & Medium & Low & High & High \\
\hline Switching costs to claimant & High/Medium & Low/Medium & Low & Medium & Medium \\
\hline Bargaining Power & Low/Medium & High & Medium/High & $\begin{array}{c}\text { Low/Mediu } \\
\text { m }\end{array}$ & \begin{tabular}{c} 
Low \\
\hline
\end{tabular} \\
\hline
\end{tabular}




\section{References}

Aguilera, R.V., Rupp, D.E., Williams, C.A. \& Ganapathi, J. 2007. Putting the S back in CSR: A multi-level theory of social change in organizations. Academy of Management Review, 32(3): 836-863.

Appleyard, M.M. 1996. How does knowledge flow? Interfirm patterns in the semiconductor industry. Strategic Management Journal, 17: 137-154.

Bapuji H. 2015. Individuals, interactions and institutions: How economic inequality affects organizations. Human Relations, 68(7):1059-1083.

Bapuji H. \& Mishra, S. Inequality and business. 2015. In Mir, R., Willmott, H., \& Greenwood, M. (Eds.), Companion to Philosophy in Organization Studies. pp 439-448. Routledge: New York.

Bapuji H, Neville L. 2015. Income Inequality Ignored? An Agenda for Business and Strategic Organization. Strategic Organization, 13(3):233-246.

Barney, J. B. 1986. Strategic factor markets: Expectations, luck, and business strategy. Management Science, 32:1231-1241.

Bartkus, B.R., Morris, S.A. \& Seifert, B. 2002. Governance and corporate philanthropy: Restraining Robin Hood? Business and Society, 41(3): 319-344.

BCG 2012. Global Wealth 2012: The Battle to Regain Strength. The Boston Consulting Group.

Bowman, C. and Ambrosini, V., 2010. How value is created, captured and destroyed. European Business Review, 22(5), pp.479-495.

Bowman, C., \& Ambrosini, V. 2000. Value creation versus value capture: Towards a coherent definition of value in strategy. British Journal of Management, 11: 1-15.

Boyd, B. K. 1994. Board control and CEO compensation. Strategic Management Journal, 15(5): 335-344.

Burt, R.S. 1983. Corporate philanthropy as a cooptive relation. Social Forces, 62(2), 419-449. CBO. 2011. Trends in the distribution of household income between 1979 and 2007.

Chasan, E. 2013. Apple now holds 10\% of all corporate cash: Moody's. Wall Street Journal. Available at http://blogs.wsj.com/cfo/2013/10/01/apple-now-holds-10-of-all-corporatecash-moodys/ accessed on October 15, 2013.

Christie, E. \& Holzner, M. 2006. What explains tax evasion? An empirical assessment based on European data. Working Paper No. 40, Vienna Institute for International Economic Studies, Vienna.

Clarkson, M.E., 1995. A stakeholder framework for analyzing and evaluating corporate social performance. Academy of Management Review, 20(1), pp.92-117.

Cobb, J.A. \& Stevens, F.G., 2016. These Unequal States Corporate Organization and Income Inequality in the United States. Administrative Science Quarterly, $10.1177 / 0001839216673823$

Cobb, J.A. and Lin, K.H., 2017. Growing Apart: The Changing Firm-Size Wage Premium and Its Inequality Consequences. Organization Science. https://doi.org/10.1287/orsc.2017.1125

Coff, R. W. 1999. When competitive advantage doesn't lead to performance: Resource-based theory and stakeholder bargaining power. Organization Science, 10: 119-133.

Coff, R.W., 2010. The coevolution of rent appropriation and capability development. Strategic Management Journal, 31(7), pp.711-733.

Cooke, Philip, Mikel Gomez Uranga, and Goio Etxebarria. "Regional innovation systems: Institutional and organisational dimensions." Research policy 26.4 (1997): 475-491. 
Crossan, M. M., Lane, H. W., and White, R. E. 1999. An organizational learning framework: From intuition to institution. Academy of Management Review, 24(3): 522-537.

David, P., O’Brien, J.P., Yoshikawa, T. \& Delios, A. 2010. Do shareholders or stakeholders appropriate the rents from corporate diversification? The influence of ownership structure. Academy of Management Journal, 53(3): 636-654.

Dean, A. \& Kretschmer, M. 2007. Can ideas be capital? Factors of production in the postindustrial economy: A review and critique. Academy of Management Review, 32(2), 573-594.

DiPrete, T.A. \& McManus, P.A. 2000. Family change, employment transitions, and the welfare state: Household income dynamics in the United States and Germany. American Sociological Review, 65(3), 343-370.

Domhoff WG. Wealth, Income, and Power. Available at http://www2.ucsc.edu/whorulesamerica/power/wealth.html Accessed on Nov 1, 2012.

Duggan, L. (2012). The twilight of equality?: Neoliberalism, cultural politics, and the attack on democracy. New York: Beacon Press.

Elmes, M.B., 2017. Economic Inequality, Food Insecurity, and the Erosion of Equality of Capabilities in the United States. Business \& Society, p.0007650316676238.

Felin, T. \& Hesterly, W.S. 2007. The knowledge-based view, nested heterogeneity, and new value creation: Philosophical considerations on the locus of knowledge. Academy of Management Review, 32(1): 195-218.

Finkelstein, S., Hambrick, D. C., \& Cannella, A. A. 1996. Strategic Leadership. St. Paul: West Publishing Company.

Fombrun, C. \& Shanley, M. 1990. What's in a name? Reputation building and corporate strategy. Academy of Management Journal, 33(2):233-259.

Freeman C. 1987. Technology policy and economic performance: Lessons from Japan. Pinter Publishers: London.

Freeman RE. 1984. Strategic Management: A Stakeholder Approach. Pitman Publishing: Boston, MA.

Ghemawat, P. (2003Q5) 'Semiglobalization and international business strategy', Journal of International Business Studies, 34(2): 138-152.

Godfrey, P.C. 2005. The relationship between corporate philanthropy and shareholder wealth: A risk management perspective. Academy of Management Review, 30(4): 777-798.

Grant, R.M. 1996. Toward a knowledge-based theory of the firm. Strategic Management Journal, 17: 109-122.

Greenberg, J. 2010. Organizational Injustice as an Occupational Health Risk. Academy of Management Annals, 4(1): 205-243.

Gunningham, N., Kagan, R.A. and Thornton, D., 2004. Social license and environmental protection: why businesses go beyond compliance. Law \& Social Inquiry, 29(2), pp.307341.

Gupta, S., Davoodi, H. \& Alonso-Terme, R. 2002. Does corruption affect income inequality and poverty? Economics of Governance, 3(1): 23-45.

Hall, R. 1993. A framework linking intangible resources and capabilities to sustainable competitive advantage. Strategic Management Journal, 14: 607-618.

Hanssen-Bauer, J. \& Snow, C.C. 1996. Responding to hypercompetition: The structure and processes of a regional learning network organization. Organization Science, 7(4): 413 427. 
Harvey, D. (2003). The new imperialism. Oxford University Press, USA.

Haslam, C., Tsitsianis, N., Andersson, T. and Yin, Y.P., 2013, December. Apple's financial success: The precariousness of power exercised in global value chains. Accounting Forum, 37(4): 268-279.

Heath, 2017. Apple's cash pile is as big as the GDP of Finland and Jamaica, combined. The Washington Post, May 1. Available at:

https://www.washingtonpost.com/business/economy/apples-cash-pile-is-as-big-as-the-gdpof-finland-and-jamaica-combined/2017/05/01/192d082c-2e7d-11e7-9dec-

764dc781686f_story.html. Accessed on June 15, 2017.

Hitt, M.A., Dacin, M.T., Levitas, E., Arregle, J. \& Borza, A. 2000. Partner selection in emerging and developed market contexts: Resource-based and organizational learning perspectives. Academy of Management Journal, 43(3): 449-467.

Hong, Q., \& Smart, M. 2010. In praise of tax havens: International tax planning and foreign direct investment. European Economic Review, 54(1), 82-95.

Hudson, I., \& Hudson, M. (2003). Removing the veil? Commodity fetishism, fair trade, and the environment. Organization \& Environment, 16(4), 413-430.

Kang, S., Morris, S.S. \& Snell, S.A. 2007. Relational archetypes, organizational learning, and value creation: Extending the human resource architecture. Academy of Management Review, 32(1):236-256.

Kaplinsky, R. \& Morris, M. (2001). A Handbook for Value Chain Research, November: report to International Development Research Center, Canada.

Katic, I. and Ingram, P., 2017. Income Inequality and Subjective Well-Being: Toward an Understanding of the Relationship and Its Mechanisms. Business \& Society, p.0007650317701226.

Kenworthy, L. 1999. Do social welfare policies reduce poverty? A cross-national assessment. Social Forces, 77(3), 1119-1139.

Kim, J., \& Mahoney, J. T. 2010. A strategic theory of the firm as a nexus of incomplete contracts: A property rights approach. Journal of Management, 36(4), 806-826.

Kim, J., Kogut, B. and Yang, J. 2013. Executive Compensation, fat cats and best athletes. Columbia Business School Research Paper. Available at SSRN: http://ssrn.com/abstract=1948531 or http://dx.doi.org/10.2139/ssrn.1948531

Kogut, B. 1983. Foreign Direct Investment as a Sequential Process, in: C.P. Kindleberger and D.B. Audretsch (eds.) The Multinational Corporation in the 1980s: 38-56. Cambridge: MIT Press.

Lazonick, W. \& O’Sullivan, M. 2000. Maximizing shareholder value: A new ideology for corporate governance. Economy and Society 29(1): 13-35.

Lee, C., Lee, K. \& Pennings, J.M. 2001. Internal capabilities, external networks, and performance: a study on technology-based ventures. Strategic Management Journal, 22(67): 615-640.

Lemieux, T. 2006. Increasing residual wage inequality: Composition effects, noisy data, or rising demand for skill? American Economic Review, 96(3):461-498.

Lepak, D.P., Smith, K.G. \& Taylor, M.S. 2007. Value creation and value capture: A multilevel perspective. Academy of Management Review, 32(1): 180-194.

Liebeskind, J. P., Oliver, A. L., Zucker, L. and Brewer, M. 1996. Social networks, learning, and flexibility: Sourcing scientific knowledge in new biotechnology firms. Organization Science, 7(4): 428-43. 
Lundvall, B. Å. 2007. National innovation systems - analytical concept and development tool. Industry and innovation, 14(1):95-119.

Mahoney, J.T. \& Qian, L. 2013. Market frictions as building blocks of an organizational economics approach to strategic management. Strategic Management Journal, 34(9), 1019-1041.

Makadok, R., \& Coff, R. 2002. The theory of value and the value of theory: Breaking new ground versus reinventing the wheel. Academy of Management Review, 27: 10 -13.

Marquis, C., Glynn, M.A. \& Davis, G.F. 2007. Community isomorphism and corporate social action. Academy of Management Review 32(3): 925-945.

McCall, L. \& Percheski, C. 2010. Income inequality: New trends and research directions. Annual Review of Sociology, 36: 329-347.

McDonnell, M. \& King, B. 2013. Keeping up appearances: Reputational threat and impression management after social movement boycotts. Administrative Science Quarterly, 58(3): 387-419.

Mir, R., Mir, A. \& Bapuji, H., 2007. Offshoring, exit and voice: implications for organizational theory and practice. Critical Perspectives on International Business, 3(3), pp.211-219.

Moir, L. \& Taffler, R.J. 2004. Does corporate philanthropy exist? Business giving to the arts in the UK. Journal of Business Ethics, 54(2): 149-161.

Moran, P. \& Ghoshal, S. 1999. Markets, firms, and the process of economic development. Academy of Management Review, 24(3), 390-412.

Mowery, David C., and Joanne E. Oxley. "Inward technology transfer and competitiveness: the role of national innovation systems." Cambridge journal of economics 19.1 (1995): 67-93.

Muller, A. \& Kraussi, R. 2011. Doing good deeds in times of need: A strategic perspective on corporate disaster donations. Strategic Management Journal, 32(9): 911-929.

Nag, R., Hambrick, D. C., \& Chen, M. J. 2007. What is strategic management, really? Inductive derivation of a consensus definition of the field. Strategic Management Journal, 28(9), 935955.

Nahapiet, J. \& Ghoshal, S. 1998. Social capital, intellectual capital, and the organization. Academy of Management Review, 23(2): 242-266.

Neckerman, K.M. \& Torche, F. 2007. Inequality: Causes and consequences. Annual Review of Sociology, 33: 335-357.

Nelson, Richard R. 1993. National Innovation Systems: A comparative analysis. New York, etc.: Oxford University Press.

Nonaka, I. 1994. A dynamic theory of organizational knowledge creation. Organization Science, 5(1): 14-37.

OECD. 2011. Divided We Stand: Why Inequality Keeps Rising. Organization for Economic Cooperation and Development, Paris: OECD Publishing.

Patel, P., \& Pavitt, K. 1994. National innovation systems: why they are important, and how they might be measured and compared. Economics of Innovation and New Technology, 3(1):77-95.

Pathak, S. and Muralidharan, E., 2017. Economic Inequality and Social Entrepreneurship. Business \& Society, p.0007650317696069.

Piketty, T. (2014). Capital in the Twenty-First Century. Cambridge, MA: Belknap Press.

Piketty, T. \& Saez, E. 2003. Income inequality in the United States, 1913-1998. Quarterly Journal of Economics, 118(1): 1-41.

Powell, W. W., Koput, K. W., \& SmithDoerr, L. 1996. Interorganizational collaboration and the 
locus of innovation: Networks of learning in biotechnology. Administrative Science Quarterly, 41(1): 116-145.

Priem, R.L. 2007. A consumer perspective on value creation. Academy of Management Review, 32(1): 219-235.

Ranjan, A. 2017. For Sardar Patel statue, oil PSUs are 'directed' to pay Rs 200 crore. Available at http://indianexpress.com/article/india/for-sardar-patel-statue-oil-psus-are-directed-topay-rs-200-crore-4690888/. Accessed on June 17, 2017.

Reverte, C. 2009. Determinants of corporate social responsibility disclosure ratings by Spanish listed firms. Journal of Business Ethics 88(2): 351-366.

Richter, B.K., Samphantharek, K. \& Timmons, J.F. 2009. Lobbying and taxes. American Journal of Political Science 53(4): 893-909.

Scully, M., Rothenberg, S., Beaton, E.E. and Tang, Z., 2017. Mobilizing the Wealthy: Doing "Privilege Work" and Challenging the Roots of Inequality. Business \& Society, p.0007650317698941.

Shah, A. \& Ramarathinam, A. 2015. Corporate dividend ratio payout at highest in at least 11 years. Livemint.com. Available at http://www.livemint.com/Companies/dfDBLg9PicEj1lTk9ltY4H/Corporate-dividendpayout-ratio-at-highest-in-at-least-11-ye.html. Accessed on June 15, 2017.

Shenkar, O. \& Li, J. 1999. Knowledge search in international cooperative ventures. Organization Science, 10(2): 134-143.

Sjoberg, O. 2009. Corporate governance and earnings inequality in the OECD countries 19792000. European Sociological Review 25(5): 519-533.

Sundaram, A. K., \& Inkpen, A. C. 2004. The corporate objective revisited. Organization Science, 15(3):350-363.

Takeishi, A. 2001. Bridging inter-and intra-firm boundaries: management of supplier involvement in automobile product development. Strategic Management Journal, 22(5): 403-433.

Trevor, C., Reilly, G. \& Gerhart, B. 2012. Reconsidering pay dispersion's effect on the performance of interdependent work: Reconciling sorting and pay equity. Academy of Management Journal, 55(3): 585-610.

Tsoukas, H. 1996. The firm as a distributed knowledge system: A constructionist approach. Strategic Management Journal, 17: 11-25.

Turban, D.B. \& Greening, D.W. 1997. Corporate social performance and organizational attractiveness to prospective employees. Academy of Management Journal 40(3), 658672.

Utting, P. 2007. CSR and inequality. Third World Quarterly, 28(4): 697-712.

Weich, S., Lewis, G. and Jenkins, S.P., 2001. Income inequality and the prevalence of common mental disorders in Britain. The British Journal of Psychiatry, 178(3), pp.222-227.

Weldon, D. 2015. Shareholder power 'holding back economic growth.' BBC News, Available at http://www.bbc.com/news/business-33660426. Accessed on June 15, 2017.

Western, B. \& Rosenfeld, J. 2011. Unions, norms, and the rise in US wage inequality. American Sociological Review, 76(4): 513-537.

Wilkinson R, Pickett K. 2009. The Spirit Level: Why Equality is Better for Everyone. Penguin Books, London.

You, J-S. \& Khagram, S. 2005. A comparative study of inequality and corruption. American Sociological Review 70(1): 136-157. 
Zucman, G., 2013. The missing wealth of nations: Are Europe and the US net debtors or net creditors?. The Quarterly journal of economics, 128(3), pp.1321-1364.

Zucman, G., 2014. Taxing across borders: Tracking personal wealth and corporate profits. The Journal of Economic Perspectives, 28(4), pp.121-148. 